\begin{tabular}{|c|c|c|}
\hline & Int.J.Curr.Microbiol.App.Sci (2021) 10(09): $586-589$ & \\
\hline FXCEIFNT & $\begin{array}{l}\text { International Journal of Current Microbiology and Applied Sciences } \\
\text { ISSN: 2319-7706 Volume } 10 \text { Number } 09 \text { (2021) } \\
\text { Journal homepage: http://www.ijcmas.com }\end{array}$ & $\$ 0$ \\
\hline $\begin{array}{l}\text { EXCELLENT } \\
\text { PUBLISHERS }\end{array}$ & & \\
\hline
\end{tabular}

Original Research Article

https://doi.org/10.20546/ijcmas.2021.1009.067

\title{
Endoparasites in Cattle in Gedarif State, Sudan
}

\author{
I. M. F. Mohamed ${ }^{1 *}$, G. A. Ahmed ${ }^{1}$, A. M. Eman ${ }^{1}$, E. S. Siham ${ }^{2}$ and M. A. Abdalla ${ }^{2}$ \\ ${ }^{1}$ Ministry of Health, Qatar Public Health Department, ${ }^{2}$ Sudan University of Science and \\ Technology, College of Veterinary Medicine, P. O. Box 204, Khartoum North, Sudan \\ *Corresponding author
}

A B S T R A C T

Keywords

Young calves, gastrointestinal tract

Article Info

Accepted:

25 August 2021

Available Online:

10 September 2021

A survey of helminth parasites of cattle was conducted in Gedarif State. The number of animals infected was 108 out of 160 . Genera of nematode parasites recovered were as follows $28.7 \%$ from the total infected parasites, trematodes were $7.3 \%$, cestodes were $1.9 \%$ and protozoan parasites were $62.0 \%$. Common parasites infected, these animals were Oesphagestom urn spp, Chaabertia spp, Ascaris spp and Eimeria spp. A strategic deworming schedule be adopted prior to occurrence of infection to the host.

\section{Introduction}

The gastrointestinal tract parasites are infections either clinically or sub- clinically, the latter, being most common and of great economic importance (Makundi et al., 1998). The indirect losses were caused by decreased growth of young calves and maturity of slaughter stock (Hansen and Perry, 1994; Chaudary et al., 2007). The study of Swai et al., (2006) revealed that low to moderate strongly eggs and coccidian oocyst counts considered to cause sub clinical infection and may be important economically leading to retarded growth rate, the animal will be more susceptible to other infections and also contaminates the pastures. In Sudan, the prevalence of helminth parasites in cattle was reported in Southern Sudan and the parasites recorded were Fasciolia gigantic, Hydatid cyst and Cysticercus bovis (Karib, 1962; Eisa et al., 1962). In a survey of internal parasites in cattle, 6 genera were encountered in Equatoria Province and 5 genera in Bahr El Gaazal Province (ET Khawad et al., 1976). In western Sudan 270 cattle were examined by El Khawad et al., (1978) and the parasites concentrated were Fasciola gigantica, Paramphistomum spp, Schistosoma bovis, Cysticercus bovis, Nematodirus spp, Oesophagestomum radiatum. Bovine coccidosis was investigated by Elbihari and Hussein (1974) and Eimeria kosti had been isolated from cow in the White Nile Province. Also Sarcocystis spp, Toxoplasma gondii and Besnoitia spp were reviewed by Gasmir et al., 
(1990). Six genera of nematodes, 2 genera of trematodes were found in cattle in Damazin District (Mohammed and Atta, 2003).

The objective of this study was to examine the parasitism in cattle in Gadarif State.

\section{Materials and Methods}

Fecal samples (about 3-5g) were obtained per rectum from 160 cattle (1-5 years old) with varying climatic conditions over a period of 9 months in Gedarif State, the animals manifested loss of weight, anorexia and diarrhoea. The site of the animals were, 9 in Gedarif center, 12 in Gadarif east, 10 in El Faw west, 107 in El Gallabat east and 22 in El Gallabat west. Individual fecal egg counts (FECs) and oocyst counts were determined by using the McMaster method (Coles, 1986).

\section{Results and Discussion}

Out of 160 cattle examined for the presence of parasitic ova and oocysts, $108(67.5 \%)$ were found to be infected with helminth parasites. Genera of nematode parasites were represented (31 samples) 19.4\%, trematodes (8 samples) $5.0 \%$, cestodes (2 samples) $1.9 \%$ and protozoan parasites (67 samples) $41.9 \%$. The most common genera of nematodes were Oesphagostomum radiatum, Chabertia Ovina and Trichostrongylus spp. The genera of trematodes were Fasciola gigantica and Schistosima bovis, whereas Monezia spp and protozoa parasites Eimeria spp (Table 1).

The amount of the eggs in these samples revealed that these worms were found to be in the rainy season (Fig. 1).

In this investigation the protozoan parasites represented high proportion in adult cattle (62.0\%). But these animals may serve as a source of infection for young calves in the herd (Radostits et al., 2007). It is interesting to note multiple infections in these animals with nematodes parasites and protozoa.

In this study, El Gallabat east revealed highest parasitic infection because there of big population of animals in the area especially during the rainy seasons. These findings are in agreement with findings of Al-Shaibani et al., (2008) who showed that the rainfall and relative humidity were important factors in determining the infections with gastrointestinal parasites.

Table.1 Helminth parasites in cattle in Gedarif State

\begin{tabular}{|c|c|c|c|c|c|}
\hline Location & $\begin{array}{c}\text { Gedarif } \\
\text { Center }\end{array}$ & $\begin{array}{c}\text { Gedarif } \\
\text { East (\%) }\end{array}$ & $\begin{array}{c}\text { Elfaw } \\
\text { West (\%) }\end{array}$ & $\begin{array}{c}\text { Elgallabat } \\
\text { East (\%) }\end{array}$ & $\begin{array}{c}\text { El } \\
\text { gallabat } \\
\text { West }(\boldsymbol{\%})\end{array}$ \\
\hline Oesphagostomum radiatum & 0.0 & 0.0 & 0.0 & 4.6 & 4.5 \\
\hline Chabertia ovina & 0.0 & 0.0 & 0.0 & 4.6 & 4.5 \\
\hline Ascaris spp & 0.0 & 0.0 & 0.0 & 5.6 & 4.5 \\
\hline Osteragia spp & 0.0 & 0.0 & 0.0 & 2.8 & 1.9 \\
\hline Trichuris spp & 0.0 & 0.0 & 0.0 & 2.8 & 0.0 \\
\hline Trichostrongylus spp & 0.0 & 0.0 & 0.0 & 2.8 & 4.5 \\
\hline Fasciola gigantica & 0.0 & 0.0 & 0.0 & 1.9 & 4.5 \\
\hline Schistosima bovis & 0.0 & 0.0 & 0.0 & 1.9 & 4.5 \\
\hline Monesia spp & 0.0 & 0.0 & 0.0 & 1.9 & 0.0 \\
\hline Eimeria spp & 66.7 & 66.7 & 30.0 & 36.4 & 50.0 \\
\hline
\end{tabular}


Fig.1 Number of infected animals in Gadarif State

No. of Infected

Animals

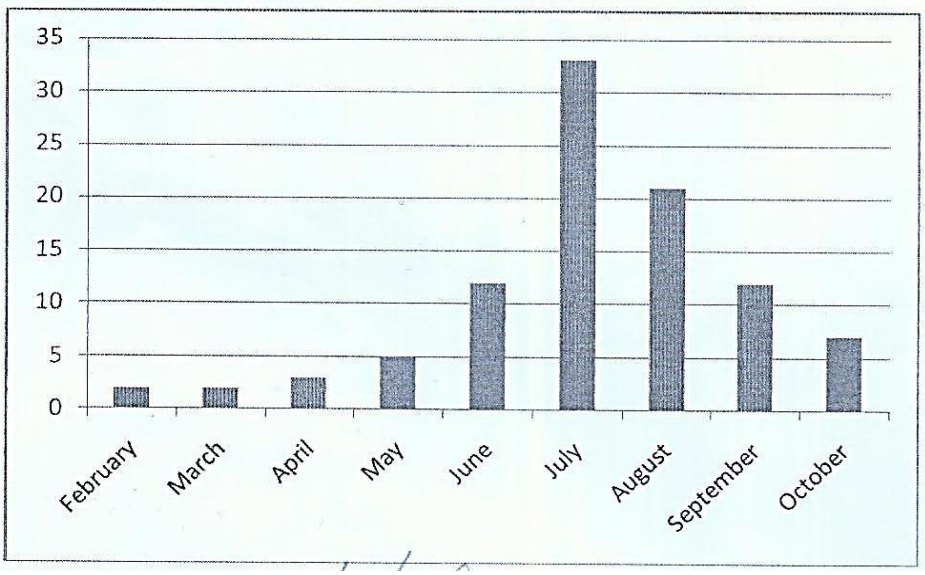

The low trematode and cestode infection may be due to using of antihelmithatics or environmental condition unsuitable.

Clinical disease intensifies with an increase in number of oocystes and / or eggs ingested and enhanced by failure of the immune response, deprivation of feed and water and shipping. The animals should be dewormed so that their parasite burden are reduced to minimum and also elimination of faces contaminated pasture. Anticoccidial and antithelimentics drugs should be used to prevent the survival of oocysts and larvae.

\section{References}

Al-Shaibani, I. R. M; Phulan, M. S.; Arijoand, A. and Qureshi, T. A. (2008). Pakistan Vet. J 28 (3): 125-130.

Chaudary, F. R.; Khan, M. F. U. and Qayyum, M, (2007). Pakistan Vet. J 27 (3): 7379.

Coles, E. H. (1986). Veterinary clinical pathology, 4th edn. W. B. Saunders Company Philadelphia, London, Toronto, Montreal, Sydney, Tokyo, pp.375-377.

Eisa, A. M.; Mustafa, A. A. and Soliman, K. A. (1962). Sud. J. Vet. Sci. Anim.Husb.

\section{3:97-108.}

Elbihari, S. and Hussein, M. F. (1974). BullEpiz. Dis. Afri 22, No., 105-107.

El Khawad, S. El Badawi, E. S.; Slepnev, N. K. and Eisa, A. M. (1976). Sud. J.Vet. Sci. Anim. Husb. 17: 86-90.

El Khawad, S. El Badaw, E. S.; Eisa,A. M.; Abubaker, M. I; Slepnev, N. K. and Gezuli, A, Y. (1978). Sud. J Vet. Sci. Anim. Husb. 19: 5 8-65.

Gasmir, G. S.; Osman, A. Y.; Shommein, A. M. and Mohammed, A. A. (1990). Sud. J Vet. Sci. Anim. Husb. 29 (1): 41- 46.

Swai, E. S.; Mtui, P. F.; Mbise, A. N.; Kaaya, E., Sanka, P. and Loomu, P. M. (2006). Liv.St.Res.Rura. Devel. 18 (8): article 107

Karib, E. A. (1962). Bull mt, Off Epiz. 58:337346.

Makundi, A. E.; Kassuku, A. A.; Maselle, R. M. and Boa, M. E. (1998). Tanz. Vet. Parasitot 75:59-6.

Mohammed, A. S. and Atta El Manan, A. M. (2003). Sud. J. Vet. Res. 18: 99-103.

Radostits, O. M.; Gay, C. C.; Blood, D. C. and Hinchcliff, K. W. (2007). Veterinary Medicine, $10^{\text {th }}$. edn. W.B. Saunders Company Ltd, London, New York, Philadelphia, San Francisco, St. Louis, Sydney, pp, 1498-1507. 


\section{How to cite this article:}

Mohamed, I. M. F., G. A. Ahmed, A. M. Eman, E. S. Siham and Abdalla, M. A. 2021. Endoparasites in Cattle in Gedarif State, Sudan. Int.J.Curr.Microbiol.App.Sci. 10(09): 586-589. doi: https://doi.org/10.20546/ijcmas.2021.1009.067 